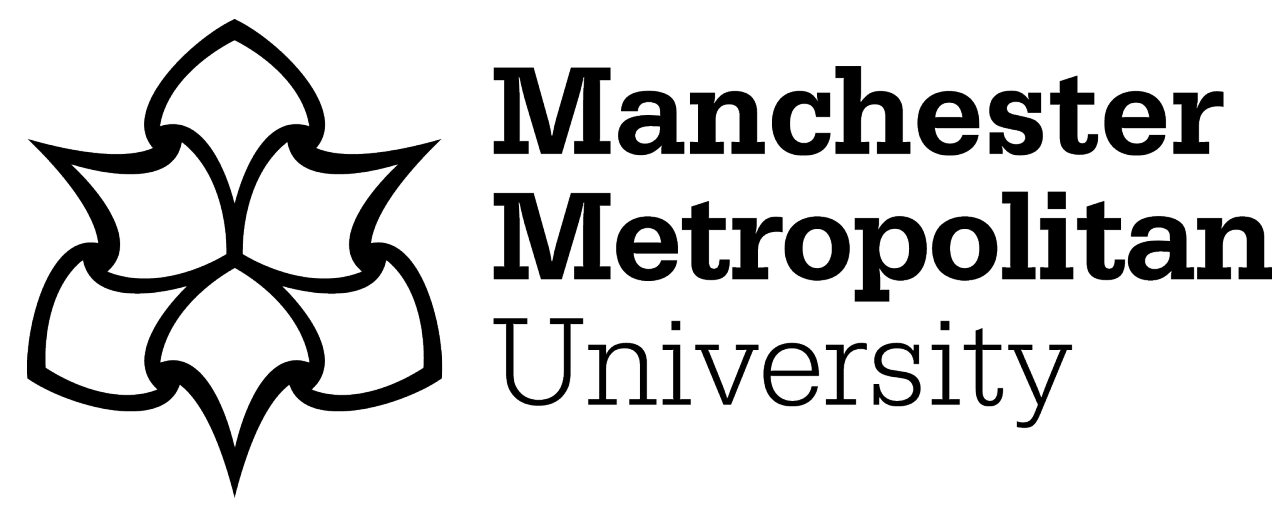

Hickey, Niall A, Shalamanova, Liliana, Whitehead, Kathryn A, Dempsey-Hibbert, Nina, van der Gast, Christopher ORCID logoORCID: https://orcid.org/0000-0003-1101-4048 and Taylor, Rebecca L ORCID IogoORCID: https://orcid.org/0000-0002-1868-2762 (2020) Exploring the putative interactions between chronic kidney disease and chronic periodontitis. Critical Reviews in Microbiology, 46 (1). pp. 61-77. ISSN 0045-6454

Downloaded from: https://e-space.mmu.ac.uk/625198/

Version: Accepted Version

Publisher: Taylor \& Francis

DOI: https://doi.org/10.1080/1040841x.2020.1724872

Please cite the published version 


\title{
Exploring the putative interactions between chronic kidney disease and chronic periodontitis
}

\author{
Niall A. Hickey ${ }^{1}$, Liliana Shalamanova ${ }^{1}$, Kathryn A. Whitehead ${ }^{1}$, Nina Dempsey-Hibbert ${ }^{1}$, \\ Christopher van der Gast ${ }^{1}$ Rebecca L. Taylor ${ }^{*}$ \\ ${ }^{1}$ Centre for Bioscience, Department of Life Sciences, Manchester Metropolitan University, \\ Manchester, United Kingdom \\ * Correspondence: \\ Rebecca Taylor \\ r.taylor@,mmu.ac.uk
}

\section{Keywords: Chronic Kidney Disease, Chronic Periodontitis, Periodontal Bacteria, Comorbidities,} Systemic Interactions.

\begin{abstract}
Chronic kidney disease and chronic periodontitis are both common diseases, which are found disproportionately comorbid with each other and have been reported to have a detrimental effect on the progression of each respective disease. They have an overlap in risk factors and both are a source of systemic inflammation along with a wide selection of immunological and non-specific effects that can affect the body over the lifespan of the conditions. Previous studies have investigated the directionality of the relationship between these two diseases; however, there is a lack of literature that has examined how these diseases may be interacting at the localized and systemic level. This review discusses how oral microorganisms have the ability to translocate and have distal effects and provides evidence for microbial involvement in a systemic disease. Furthermore, it summarizes the reported local and systemic effects of chronic kidney disease and chronic periodontitis and discusses how the interaction of these effects may be responsible for directionality associations reported.
\end{abstract}

\section{$1 \quad$ Introduction}

Chronic kidney disease (CKD) is one of the most common chronic diseases with the worldwide prevalence estimated to be approximately $13.4 \%$ and projected to continue to rise annually, especially in developing countries where renal healthcare is limited (Couser et al., 2011, Hamer and El Nahas, 2006, Coresh, 2017). Chronic Periodontitis (CP) is a chronic infection of the supporting structures of teeth that is predominately found in adults and the elderly. This definition has now been reclassified as periodontitis which includes both CP and aggressive periodontitis (Caton et al., 2018) but for the purposes of this review the previous classification of $\mathrm{CP}$ is utilized in order remain consistent with previous literature. $\mathrm{CP}$ is ubiquitous, with worldwide prevalence of severe periodontitis estimated to be approximately 7.4\% (Frencken et al., 2017, Kassebaum et al., 2017). As chronic diseases persist for long periods, there is a significant amount of comorbidity in patients, especially with other chronic diseases (Jones, 2010, Schellevis et al., 1993). Indeed, these comorbidities have been reported as a source of adverse outcomes (Tonelli et al., 2015) and highlight that complex interactions between chronic diseases could lead to effects that are detrimental for the health of the patient.

There have been reports highlighting a link between CKD and CP, which both have an overlap in terms of risk factors. While some studies have reported significant associations between both diseases, there 
is increasing evidence suggesting a directional link between $\mathrm{CKD}$ and $\mathrm{CP}$ that can affect their progression and cause adverse outcomes (Zhao et al., 2018). Both CKD and CP have well documented systemic effects on the body such as chronic inflammation and dysfunction of immune cells (Oberg et al., 2004, Vaziri et al., 2012, Akar et al., 2011, Loos, 2005); however, how their individual systemic effects may interact with each other is relatively unstudied. Furthermore, the combined effect of both chronic diseases on the localised site of periodontal disease (the oral cavity and periodontium) has not been fully elucidated and may explain why both diseases have been reported to have a detrimental effect on each other.

This review is focused on $\mathrm{CKD}$ and $\mathrm{CP}$ and how the progression of both diseases can cause a series of systemic and local changes. Particular attention will be paid to the selection of oral microorganisms that can elicit distal pathogenic effects, of which some overlap with CP associated microorganisms and discusses inconsistencies regarding the causative bacterial species that may be involved in CP. Furthermore, the review will discuss how the systemic and localised effects of each disease may interact with each other and how these interactions may lead to positive associations between CKD and $\mathrm{CP}$.

\subsection{The Oral Microenvironment}

The mouth is one of the most biologically complex regions in the mammalian body. It provides an entrance and transit point for both the digestive and respiratory systems, plays a role in rudimentary pre-processing of food, and is pivotal for oral communication and sensory functions (Marsh et al., 2009). Within the oral cavity there are the hard tissues of the teeth which are lined by the gingiva or mucosa in cases where keratinised gingiva are present, there are also a selection of soft mucosal structures such as the tongue, soft and hard palate and cheeks along with the specialized connective tissue known as the periodontium (German and Palmer, 2006). The periodontium comprises of the gingiva, alveolar bone, the cementum and the periodontal ligament and plays an important role in the attachment of the teeth to alveolar bone. The substantial variety of structures in the oral cavity provide an array of microhabitats for the large numbers of diverse microorganisms present (German and Palmer, 2006, Marsh, 2000). In this environment the two key biofluids, saliva and gingival crevicular fluid (GCF), play an important physiological role. The saliva is the predominant oral fluid. It acts as a lubricant, assists in preliminary digestion through the action of enzymes such as lipase and amylase, and plays a role in the forming of a food bolus and taste (Edgar et al., 2004). Furthermore, it is rich in antimicrobial compounds such as hydrogen peroxide, lactoferrin and lysozymes allowing it to act as protective barrier to opportunist microbes, along with being a promoter of wound healing amongst other (Vila et al., 2019). In contrast, the GCF is normally present in small amounts bathing the gingiva. However, in pathological conditions (e.g. local inflammation), the secretion of GCF increases significantly as a defensive mechanism in the immune response (Taylor and Preshaw, 2016). Although, this can also have an opposite effect as the increased GCF flow and inflammation can also promote the accumulation of inflammophilic periodontal microorganisms by providing a greater nutrient source and suitable physical environment, creating a positive feedback cycle (Marsh, 1994, Smalley, 1994).

The microorganisms in the oral cavity change in response to a wide variety of stimuli such as dietary energy sources, age, host and bacterial metabolite production, poor oral hygiene and systemic diseases (Rasiah et al., 2005). Over 700 microbial species have been characterised in the human oral cavity alone, highlighting the high levels of diversity (Dewhirst et al., 2010). This resident microbiota does not have a singularly passive relationship with the host since it contributes to the host defences, can synthesise vitamins which are beneficial to the host and plays a vital role in preventing colonisation of potential pathogens (Marsh, 2000, Kumar et al., 2013). However, as the oral cavity is a key barrier and 
entry point between the external environment and the body, it is open to opportunist pathogens that can infiltrate the blood, the lower respiratory tract and the digestive system (Tada and Hanada, 2010). Despite much of the microbiota living in symbiosis with the host, the oral cavity can further act as a reservoir for infection with many commensal microorganisms being the cause of opportunist infections in immunocompromised individuals (Gendron et al., 2000, Akpan and Morgan, 2002).

\subsection{Chronic Periodontitis}

Periodontitis is the inflammation and infection of the periodontium, which is due to the accumulation of sub-gingival dental plaque and is mediated by a wide spectrum of oral microorganisms (Hajishengallis, 2015). It predominately presents as repetitive inflammation, recession of the gingiva, gingival bleeding and the formation of periodontal pockets (Schatzle et al., 2004). The disease can be classified into four different stages (Stages 1-4) dependent on the severity of the disease, which is determined by assessment of a selection of variables such as clinical attachment loss, amount and percentage of bone loss, probing depth, presence and extent of angular bony defects and furcation involvement, tooth mobility and tooth loss due to periodontitis (Caton et al., 2018).. There are three identified pathophysiological types of periodontitis: necrotizing periodontitis, periodontitis as a manifestation of systemic disease and the forms of the disease previously recognized as "chronic" or "aggressive" which are now referred to as periodontitis (Caton et al., 2018). For the purpose of this review we are utilising the previous definition of chronic periodontitis which represents the forms of destructive periodontal disease that are generally characterised by slow progression (Papapanou et al., 2018), due to this being consistently used to define the subtype of periodontitis throughout the literature reviewed. CP is categorised by the formation of periodontal pockets of which increase in depth with the severity of the disease and provide a space for the aetiological microorganisms. It has been reported that $45 \%$ of adults in England have at least one periodontal pocket, with $8 \%$ of the population having severe periodontal pocketing (Heidari et al., 2015). The worldwide prevalence of severe CP was estimated to be 7.4\%, making it the sixth most prevalent disease worldwide (Frencken et al., 2017, Kassebaum et al., 2017). CP is of particular interest as it is a global chronic disease and can be detrimental to the health of the patient and a risk factor for myriad other diseases such as Alzheimer's (Dominy et al., 2019), cardiovascular disease (Dietrich et al., 2008), diabetes mellitus (Engebretson et al., 2013), chronic obstructive pulmonary disease (Usher and Stockley, 2013) and pre-term birth (Marsh et al., 2009, Han et al., 2004).

The main aetiological agents driving the inflammatory processes in $\mathrm{CP}$ are the plaque associated oral bacteria which form biofilms and dysregulate the normal oral microbiota (Wahid et al., 2013). CP is caused by the inflammatory response to dental plaque accumulation which can result in an increased flow of GCF, this increased flow has been shown to further favour the growth of anaerobic microorganisms (Marsh et al., 2009, Winning et al., 2015). These Gram-negative anaerobes include Porphyromonas gingivalis, Tannerella forsythia and Treponema denticola, which have been isolated from the majority of CP cases and are referred to as the 'red complex' (Wade, 2013, Socransky et al., 1998). Indeed, the levels of $P$. gingivalis and $T$. denticola in subgingival plaque can predict the progression of $\mathrm{CP}$, highlighting the key role of these organisms in the pathogenesis of CP (Byrne et al., 2009). Previously it was thought that these 'red complex' organisms affected the signalling pathways of the human host, which led to a dysbiosis of the oral microbiota thereby resulting in disease (Darveau, 2010, Socransky et al., 1998). However, it has since become apparent that CP is more complex than a singular group of organisms, with a current predominating theory being the Polymicrobial Synergy and Dysbiosis (PSD) model (Hajishengallis and Lamont, 2012). 
In the PSD model of CP, keystone pathogens such as those of the 'red complex' colonise the gingiva, interact with accessory organisms and increase the virulence of the community causing dysbiosis and disruption of homeostasis, which leads to destruction of tissue (Hajishengallis and Lamont, 2012, Payne et al., 2019). In this model, there are a wide range of microorganisms involved, with keystone pathogens such as the aforementioned 'red complex' and periodontitis accessory organisms (Table 1). These accessory organisms are predominately commensals commonly found in the healthy microbiota, which can interact with the keystone pathogens to assist in the pathogenesis of CP. However, due to the complicated nature of these interactions such as specific adhesion, metabolic symbiosis, complex biofilm formation and virulence modulation, many of the mechanisms are yet to be elucidated (Shaikh et al., 2018).

Table 1. List of key pathogens and accessory organisms with the reported roles in periodontal disease

$\underline{\text { Keystone Pathogens }}$

\begin{tabular}{|c|c|c|}
\hline Name & Reported Roles & Ref \\
\hline $\begin{array}{l}\text { Porphyromonas } \\
\text { gingivalis }\end{array}$ & $\begin{array}{l}\text { A key pathogen in CP because of complex host-pathogen and community interactions, which } \\
\text { can cause dysbiosis and promote a pro-inflammatory phenotype. In addition, a multitude of } \\
\text { virulence factors are produced which can cause damage and destruction of the periodontium. }\end{array}$ & $\begin{array}{l}\text { (Hajishengallis, } \\
\text { 2009) }\end{array}$ \\
\hline $\begin{array}{l}\text { Tannerella } \\
\text { forsythia }\end{array}$ & $\begin{array}{l}\text { A key pathogen associated with the clinical attachment loss seen in } \mathrm{CP} \text { and has been shown to } \\
\text { cause alveolar bone loss. It has a few identified virulence factors and many synergistic } \\
\text { associations with accessory organisms. }\end{array}$ & $\begin{array}{l}\text { (Kesavalu et al., } \\
\text { 2007) }\end{array}$ \\
\hline $\begin{array}{l}\text { Treponema } \\
\text { denticola }\end{array}$ & $\begin{array}{l}\text { A key pathogen of } \mathrm{CP} \text { of which the severity of the disease can be predicted by levels of } P \text {. } \\
\text { gingivalis and } T \text {. denticola. Also has a multitude of virulence factors, which assist with } \\
\text { adherence, instigating dysbiosis in the subgingival microbiota and damaging the gingival } \\
\text { tissues. }\end{array}$ & $\begin{array}{l}\text { (Byrne et al., } \\
\text { 2009, Dashper et } \\
\text { al., 2011) }\end{array}$ \\
\hline
\end{tabular}

$\underline{\text { Accessory Organisms }}$

\begin{tabular}{ll}
\hline Name & Reported Roles \\
\hline $\begin{array}{l}\text { Actinomyces } \\
\text { israelii }\end{array}$ & $\begin{array}{l}\text { Present in patients with CP more frequently than healthy patients, along with those with high } \\
\text { scores on the plaque index. It may play a role in the maturation of sub and supra gingival al., } \\
\text { plaque. It is commonly isolated alongside } \text { A. actinomycetemcomitans suggesting synergy in änen } \\
\text { periodontal infection. }\end{array}$
\end{tabular}

\begin{tabular}{ll}
\hline $\begin{array}{l}\text { Aggregatibacter } \\
\text { actinomycetemco }\end{array}$ & $\begin{array}{l}\text { A facultative anaerobic organism commonly associated with CP. It has numerous reported } \\
\text { virulence factors promoting periodontal disease with stimulation of inflammatory cytokines } \\
\text { mitans }\end{array}$ \\
$\begin{array}{l}\text { and the production of a leukotoxin, which is reported to be pro-apoptotic towards gingival } \\
\text { epithelial cells. }\end{array}$
\end{tabular}

\begin{tabular}{|c|c|c|c|}
\hline Campylobacter & & $\begin{array}{l}\text { Campylobacter organisms are not common commensals but present as transient members of } \\
\text { the healthy microbiota. } C \text {. rectus is predominately found in initial periodontal lesions and }\end{array}$ & (Macuch and \\
\hline $\begin{array}{l}\text { (C. rectus, } \\
\text { showae) }\end{array}$ & $C$. & $\begin{array}{l}\text { shallower pockets, which leads to suggestions it may play a role in the initiation of } \\
\text { periodontitis. } C \text {. showae is predominately found in deeper pockets and later stages of CP with } \\
\text { its role in the pathogenesis relatively under studied. }\end{array}$ & \\
\hline
\end{tabular}

Eubacterium Commonly mistaken for $A$. israelii due to similar morphology. It is reported to be a key nodatum accessory organism in periodontitis along with having synergy with $T$. denticola in the induction of periodontitis. However, due to misidentification there is a lack of studies looking 2014) at the interplay of this organism in CP. 


\begin{tabular}{|c|c|c|}
\hline $\begin{array}{l}\text { Fusobacterium } \\
\text { nucleatum }\end{array}$ & $\begin{array}{l}\text { Reported to play a role as a 'bridge' for early and late colonisers to co-aggregate. It has also } \\
\text { been reported to have synergy with T. forsythia in inducing an immune response and causing } \\
\text { alveolar bone loss. }\end{array}$ & $\begin{array}{l}\text { (Settem et al., } \\
2012)\end{array}$ \\
\hline $\begin{array}{l}\text { Parvimonas } \\
\text { micra }\end{array}$ & $\begin{array}{l}\text { A commensal organism commonly found in the subgingival plaque and in periodontal plaque } \\
\text { forms in the top layer. It is not thought to form biofilm structures, but has a significant } \\
\text { association with periodontal destruction. However, it is relatively understudied in CP so many } \\
\text { the biochemical interactions are unknown. }\end{array}$ & $\begin{array}{l}\text { (Zijnge et al., } \\
2010, \text { Al-hebshi } \\
\text { et al., 2014) }\end{array}$ \\
\hline $\begin{array}{l}\text { Prevotella } \\
\text { (P. intermedia, } P \text {. } \\
\text { melaninogenica, } \\
\text { P. nigrescens) }\end{array}$ & $\begin{array}{l}\text { These are anaerobic commensal organisms within supragingival plaque, which increase in } \\
\text { prevalence with periodontal disease. Biofilms produced by Prevotella spp can be used to } \\
\text { subvert the innate immune system causing the periodontal plaques to chronically colonise the } \\
\text { periodontal pockets. Furthermore, it has also been reported that } P \text {. intermedia can release pro- } \\
\text { inflammatory cytokines and matrix metalloproteinases, which can stimulate periodontal } \\
\text { destruction. }\end{array}$ & $\begin{array}{l}\text { (Stingu et al., } \\
\text { 2013, Tanaka et } \\
\text { al., 2008, Fukui et } \\
\text { al., } 1999 \text {, } \\
\text { Yamanaka et al., } \\
\text { 2009, Guan et al., } \\
\text { 2008) }\end{array}$ \\
\hline $\begin{array}{l}\text { Streptococcus } \\
\text { anginosus group } \\
\text { (S. anginosus, } S \text {. } \\
\text { constellatus, } \quad \text { S. } \\
\text { intermedia) }\end{array}$ & $\begin{array}{l}\text { This group are commensals that inhabit the subgingival periodontal pockets in those with } \\
\text { periodontitis and are usually present even after treatment. It has been suggested that they } \\
\text { provide an attachment substratum, which can allow for recolonization of periodontal pathogens } \\
\text { after treatment as they have strong anti-phagocytic resistance to leukocytes. }\end{array}$ & $\begin{array}{l}\text { (Rams et al., } \\
2014)\end{array}$ \\
\hline $\begin{array}{l}\text { Streptococcus } \\
\text { mitis group } \\
\begin{array}{ll}\text { (S. gordonii, } & \text { S. } \\
\text { sanguinis, } & \text { S. } \\
\text { oralis) }\end{array}\end{array}$ & $\begin{array}{l}\text { This group are thought to assist the key pathogens in adherence by providing an attachment } \\
\text { substratum and facilitate signal transduction. Furthermore, synergy between } S \text {. gordonii, } P \text {. } \\
\text { gingivalis and } A \text {. actinomycetemcomitans has been demonstrated causing increased } \\
\text { pathogenicity when in co-culture. }\end{array}$ & $\begin{array}{l}\text { (Whitmore and } \\
\text { Lamont, 2011, } \\
\text { Hendrickson et } \\
\text { al., 2017) }\end{array}$ \\
\hline
\end{tabular}

Infection of the periodontium can provide a method of systemic entry into the body for microorganisms along with microbial products and potential antigens. These may induce inflammatory responses in distant tissues by dissemination using the circulatory system (Bastos et al., 2011), with evidence of this seen in infective endocarditis (Baddour et al., 2015) and infective glomerulonephritis (Brodsky and Nadasdy, 2017). In addition, CP associated microorganisms and products are released into the digestive system by the swallowing of the inflammatory exudate, periodontal bacteria and bacterial products (Olsen and Yamazaki, 2019).

\subsection{Chronic Kidney Disease}

The kidneys play a vital role in the body by filtering blood and metabolic waste, while also modifying the content and composition of fluids in the body. They facilitate waste excretion, nutrient reabsorption, secrete hormones, regulate osmolarity, regulate blood pressure and maintain systemic acid base homeostasis (Jameson and Loscalzo, 2016). The anatomy of the kidney reflects its unique role in the body with the functional unit of the kidney being the nephrons, which filter the blood to form urine. Damage to the nephrons can lead to acute or chronic kidney diseases, which may predispose to multiple diseases or lead to end-stage renal failure which requires dialysis or transplantation (Hoy et al., 2005).

It is estimated that in England 2.6 million people aged 16 years and older have CKD stage 3-5 which equates to $6.1 \%$ of the general population (Aitken, 2014). Chronic Kidney Disease (CKD) is defined as reduced kidney function that is present for over three months, and has implications for the health of the patient such as kidney failure and cardiovascular death (Inker et al.). The reduced kidney function is measured using the estimated glomerular filtration rate (eGFR), with the severity of CKD staged 
from 1-5 based on the decrease in eGFR (Hemmelgarn et al., 2010). CKD often goes undiagnosed and can present idiopathically along with co-morbidities such as diabetes, cardiovascular disease and chronic periodontitis (Levey et al., 2003, Dyck et al., 2012, Borawski et al., 2006). The progression of CKD is characterised by the loss of renal cells and the replacement of these with extracellular matrix, which leads to the reduction of renal function and related symptoms such as uremia, proteinuria and oedema (Nogueira et al., 2017).

The function of the kidney in acting as a filtering agent of waste products for the blood increases their risk of damage by toxins (Finn, 1977a). The blood flow to the kidney is greater per gram of tissue compared to any other organ (Finn, 1977b) meaning that the total amount of waste/toxins delivered will be disproportionately high. Furthermore, as the kidneys are able to concentrate substances through filtration, reabsorption and secretion, this can cause various metabolites and toxins to build up to levels which can be damaging to the nephrons (Finn, 1977b).

Many factors increase the risk of CKD such as age, gender, ethnicity, concurrent diseases such as hypertension and diabetes and socio-economic status (Kazancioglu, 2013). Indeed, a key strategy for management of CKD is identification of modifiable risk factors, which would allow for earlier detection of the disease. The identification of predisposing risk factors for CKD can also allow intervention-based strategies to facilitate early treatment of the disease. Current research has focused on investigating risk factors that may have a directional link with CKD independent of other risk factors such as Alzheimer's Disease (Shi et al., 2018), obstructive sleep apnoea (Mirrakhimov, 2012) and CP (Wahid et al., 2013, Pradeep et al., 2012). Identification of these directional risk factors is of particular importance, as many of these can have a significant impact on progression of both diseases and if controlled could be a useful treatment to deal with both diseases.

\section{Oral Bacteria and Distal Pathogenic Effects}

Although the effect of pathogenic oral bacteria on the health and disease of the oral cavity has been acknowledged for many years, the interplay between these organisms and other systemic diseases has only recently re-emerged. The first proposal of distal pathogen effects by microorganisms was in 1891 with W. Miller suggesting that oral microorganisms could access distal body parts known as the focal infection theory (Miller, 1891). This was built upon and suggested to be the cause of a number of systemic diseases such as endocarditis, diabetes and nephritis (Billings, 1916). At the time these suggestions were not taken seriously however the proposal re-emerged in the 1990's with the American Academy of Periodontology and the world workshop in periodontitis suggesting that oral infection is frequently related to local and general disease (Scannapieco, 1998). This has led to modernisation of the focal infection theory to the periodontal medicine concept which highlights the relationship between chronic periodontitis and systemic disease, with oral status connected to systemic health (Pizzo et al., 2010).

Many of these putative links have been identified through epidemiological associations adjusted for known risk factors. However, the mechanisms behind many of these interactions still need to be elucidated (Seymour et al., 2007). There are a few known case studies of distal pathogen effects from oral microorganisms namely: bacterial endocarditis, acute post-streptococcal glomerulonephritis and infective endocarditis glomerulonephritis (Carapetis et al., 2005, Lusco et al., 2016, Majumdar et al., 2000).

\subsection{Translocation of Oral Pathogens}


In a healthy mouth, the mucous membrane along with host-produced antimicrobial molecules such as defensins provide a barrier to external pathogens, preventing the commensal and opportunist microbes from damaging the host. This barrier can be disrupted in multiple ways including physical disruption via trauma such as micro abrasions caused by tooth brushing (Addy and Hunter, 2003), by periodontal pathogens invading the gingival margin (Bosshardt, 2017) or if a host is immunocompromised through medication or disease where they are more at risk of infection.

There are three possible mechanisms of how oral microbes can facilitate further diseases: (1) infection due to metastatic transient bacteremia; (2) metastatic immunological injury and; (3) metastatic toxic injury (Thoden van Velzen et al., 1984, Pizzo et al., 2010). Metastatic transient bacteremia refers to the damage caused by translocation of microorganisms throughout the body. Metastatic immunological injury refers to the damage caused by the stimulation of an immune response such as the process of inflammatory mediation seen in chronic periodontitis by the microorganisms involved. This could also encompass the generation of epitopes by periodontal microorganisms, which have been reported to have a high degree of similarity with human tissue autoantigens related to a selection of autoimmune diseases (Obando-Pereda, 2018). Metastatic toxic injury is the damage caused by the release of toxic compounds which can be produced by microorganisms or by components of the cell ultrastructure such as Lipopolysaccharide (LPS) or endotoxins which can stimulate an immune response through host toll like receptors (TLRs) (Gendron et al., 2000, Aderem and Ulevitch, 2000).

\subsection{Bacteremia}

Bacteremia is defined as the presence of viable bacteria in the bloodstream, with primary bacteremia occurring through direct access from the outer environment such as through injection or venipuncture, and secondary bacteremia being related to the disruption of a local barrier such as the mucosal membranes or wounds (Jawetz, 2007). Bacteremia can be categorized based on the longevity of the microorganisms in the bloodstream: transient, intermittent or persistent (Poveda-Roda et al., 2008). Transient bacteremia originating from the oral cavity is a relatively common event which can be caused by dental procedures including daily oral hygiene routines, such as tooth brushing and flossing, and while being asymptomatic it usually only lasts for approximately an hour (Everett and Hirschmann, 1977). In contrast, intermittent and persistent bacteremia are not as common and are associated with increased severity of periodontal disease and accumulation of plaque within the gingival crevice and periodontal pocket.

Bacteremia is particularly common in $\mathrm{CP}$, with the bacteria and their products being able to enter the bloodstream through the inflamed gingiva and elicit a response in distal tissues (Fisher et al., 2010). For example the key CP pathogen $P$. gingivalis has been isolated from atherosclerotic plaques (Serra e Silva Filho et al., 2014), the placenta (Katz et al., 2009), the liver (Ishikawa et al., 2013) and is capable of invading arterial cells (Deshpande et al., 1998) and causing endothelial dysfunction (Tonetti et al., 2007). The accessory organism $A$. actinomycetemcomitans has also been isolated from periodontal pockets and atherosclerotic plaques (Padilla et al., 2006). While the microbiota of periodontal and atheromatous plaques has been reported to be highly similar, indicating translocation rather than sporadic infection (Serra e Silva Filho et al., 2014), there is currently no study to demonstrate the clonal nature between periodontal plaques and atherosclerotic plaques.

\subsection{Bacterial Endocarditis}


Bacterial endocarditis (BE) is an infection of the inner lining of the heart, most commonly the heart valves but it can also affect artificial implants such as pacemakers and artificial valves (Carmona et al., 2002). This infection is caused by a subset of circulating microorganisms that can bind to the endocardium, or an abrasion/micro-clot already present, forming a biofilm. This can lead to the activation of complement and formation of a clot with a notable absence of white blood cell recruitment (Cabell et al., 2003). It is a relatively uncommon disease with an incidence of 2.3 cases per 100,000 people in the UK, with a poor prognosis in lower income countries (Ambrosioni et al., 2017).

Oral microorganisms such as Streptococcus mutans and Streptococcus sanguinis were previously the most common microorganisms isolated as causative agents of bacterial endocarditis, most likely due to their strong thrombogenic potential which allows adherence to the surfaces of the heart (Coykendall, 1989). Bacterial adherence is related to intrinsic dextran production, which allows attachment to the heart valves along with fibrin and platelets leading to the formation of plaques (Scheld et al., 1978).

Renal glomerular lesions have been reported in cases of BE (Majumdar et al., 2000). The pathogenesis of endocarditis related glomerulonephritis is similar to acute post-streptococcal glomerulonephritis, as both are a form of infective glomerulonephritis. Infective Endocarditis Glomerulonephritis (IEGN) is be mainly caused by Staphylococcus aureus endocarditis with Streptococcal endocarditis being the second most common pathogen, they both can lead to tubular damage as identified by renal biopsies (Boils et al., 2015). Previous work investigating pathogenesis of the IEGN had identified the activation and deposition of $\mathrm{C} 3$ of the complement cascade and the involvement of IgG antibodies (Boils et al., 2015). However many of these studies used cadaver kidneys and more recent renal biopsy studies demonstrated that the activation of $\mathrm{C} 3$ is the primary cause of damage, with IgG and other antibodies being present in a much smaller amount (Bayer and Theofilopoulos, 1990). These studies demonstrate that IEGN is more complex than previously thought and the activation of the complement cascade may be stimulated by various virulence factors such as Staphylococcal superantigens which may cause direct tissue damage (Salgado-Pabon et al., 2013) and various immunological complexes produced by Streptococci as further discussed in the related acute post-streptococcal glomerulonephritis condition.

\subsection{Evidence for Kidney damage induced by Oral Microorganisms}

Although several reports link oral microorganisms and kidney damage there are inconsistencies regarding the causative species, type of damage and putative mechanisms of damage (Nasr et al., 2008, Trivedi et al., 2017, Ramanathan et al., 2017, Nasr et al., 2011). Acute post-streptococcal glomerulonephritis (APGN) is a well-studied example of pathogenic oral microorganisms eliciting a distal response and damage to kidneys.

APGN represents an inflammation of the glomeruli in the kidneys and is widely attributed to group A streptococci (Ahn and Ingulli, 2008). AGPN is one of the most common nephric conditions, with over 490,000 cases estimated globally per year. The majority of the AGPN cases occur in developing countries and are easily treated with antibiotics (Carapetis et al., 2005). As group A streptococci can be present in the oral and skin microbiota, the source of infection mainly depends on the climate, with the colder climates associated with upper respiratory tract infections and warmer climates with skin infections (Earle, 1985). In one such case, swabs were taken from four neighbouring rural families who contracted acute glomerulonephritis (Almroth et al., 2005). Kidney biopsies of the patients showed acute diffuse proliferate glomerulonephritis, which could be a consequence of streptococcal nephritis, with Streptococcus constellatus and Streptococcus pyogenes being isolated from these biopsies. While the direct mechanism for this kidney damage is unknown, it has been suggested that the poststreptococcal glomerulonephritis could be caused by deposition of nephrogenic streptococcal proteins 
in the glomerulus and the production of an antibody-mediated response (Cronin et al., 1989) or deposition of bacterial toxins in the kidneys. A recent review on this topic suggests that this pathogenesis was probably immunological rather than toxin-related, as the level of observed kidney damage is not proportional to the infection as is the case in other toxin mediated diseases (Brodsky and Nadasdy, 2017). A number of streptococcal proteins have been identified (e.g. nephritis strainassociated protein (Ohkuni et al., 1983), Endostreptosin (Yoshizawa et al., 1997) and streptococcal M protein (Vosti et al., 1971)) with these having detectable antibody titres in a large proportion of patients. However, the lack of specificity to acute post-streptococcal glomerulonephritis of these proteins is a major drawback in the identification of causative agent(s). This has led to other mechanisms such as autoimmunity (Zabriskie et al., 1970) and coagulation (Alkjaersig et al., 1976) to be proposed as playing a role in the disease.

\section{The Systemic Effects of CKD and CP}

Systemic disease refers to a disease affecting the whole body rather than a single body part such as the oral cavity ( $\mathrm{Li}$ et al., 2000). With chronic diseases, the long-term exposure to various by-products of the disease and complications related to disruptions in homeostasis can lead to distal effects in a variety of body functions and sites. These distal effects could conceivably lead to predisposition to other chronic diseases, especially as many have overlapping risk factors, and could be a key reason as to why many chronic diseases are comorbid within chronic disease populations (Jones, 2010).

\subsection{The Systemic Effects of CP}

Although it has been suggested that the oral cavity might provide an entry point to multiple diseases, how this is accomplished and what systemic consequences it can produce has only been partly explained. Recent research has demonstrated that $\mathrm{CP}$ is linked with diseases outside of the oral cavity, such as atherosclerosis, diabetes, stroke and coronary heart disease, with the pathogenesis mechanisms being under investigation (Gualtero et al., 2018, Sen et al., 2018, Beck et al., 2018, Preshaw et al., 2012). Many of the systemic effects associated with CP are resultant of the dysbiosis of oral microbiota, and the dissemination of the microorganisms or their products to distal parts of the body. With this in mind, it may be hypothesized that a similar systemic oral link may be influencing the incidence of CKD (Figure 1).

$\mathrm{CP}$ has an effect on the oral cavity over the course of the disease in numerous ways. It can modify the site of the infection, the periodontium, and the wider oral cavity. This is evidenced by disruption of the microvasculature (Zoellner et al., 2002), loss of attachment of teeth and bone damage (Flemmig, 1999), gingival bleeding (Albandar and Kingman, 1999) and the formation of periodontal pockets up to 1500$2000 \mathrm{~mm}^{2}$ (Loos, 2006) with bacteria potentially in excess of $1 \times 10^{8}$ colony forming units in each pocket (Pihlstrom et al., 2005). The local production of inflammatory cytokines interleukin-6 and tumour necrosis factor- $\alpha$ in CP can increase the systemic levels of C-reactive protein and thus induce systemic inflammatory effects (Moutsopoulos and Madianos, 2006, Dye et al., 2005, Slade et al., 2003).

The localised damage to the oral cavity and periodontium along with the systemic inflammation can have a detrimental effect on the consumption of food and medication in CKD patients, affecting their quality of life and potentially leading to malnutrition and predisposition to other diseases (Anand et al., 2013, Akar et al., 2011, Chen et al., 2006). Indeed, the systemic inflammatory effects of CP could be predicted to exacerbate the inflammation already present in CKD with potential interactions possibly acting as a further stressor on the already damaged kidneys. 


\subsection{The Systemic Effects of CKD}

CKD causes a multitude of systemic effects on the human body, which are due to the kidneys progressively failing to remove waste products from the blood. Over time, this can lead to long-term exposures of the body to a variety of uremic toxins (e.g. amino acid metabolic products such as urea and creatinine) (Vanholder et al., 2003). This can lead to the development of uremic syndrome (uremia), which results in the accumulation of organic waste products which would normally be cleared by the kidneys (Inker and Levey, 2014, Meyer and Hostetter, 2007). Alongside this, in CKD changes are observed in processes linked to the normal function of the kidney such as the regulation of blood pressure and the homeostasis of electrolytes and acid-base balance (Dhondup and Qian, 2017), which lead to hypertension (Judd and Calhoun, 2015), hyperphosphatemia (Hruska et al., 2008), and hypocalcaemia (Kalantar-Zadeh et al., 2010). There are a multitude of other non-specific effects of CKD, such as a general inflammation, infection and protein wasting (Akar et al., 2011).

The oral cavity is a site where the systemic effects of CKD have been reported and is of particular interest as it encompasses gingival tissue, the site for CP pathogenesis. The effects are multifaceted and dependent on factors such as: the drugs used for the treatment of CKD, the stage of CKD, dialysis status, oral healthcare regime and confounding diseases such as diabetes. Increased plaque, gingival inflammation and calculus have been extensively reported (Craig, 2008). Although the cause is not clear, as other factors such as immune dysfunction, confounding diseases and poor oral hygiene may play a role. It has also been reported that oral lesions are much more common in CKD patients who display increased serum urea concentrations and elevated $\mathrm{pH}$ in the oral cavity (Honarmand et al., 2017, Oyetola et al., 2015). There are a large selection of other changes to the oral cavity reported to take place in CKD such as changes to teeth, periodontium, oral mucosa, bone and tongue (Akar et al., 2011, Craig, 2008). With multiple reports highlighting the increased incidence of periodontal disease in those with CKD it is possible that changes in the oral cavity may predispose CKD patients to developing CP (Ariyamuthu et al., 2013).

With the onset of CKD, increasing levels of urea in the oral cavity can lead to a range of changes that contribute to the development of $\mathrm{CP}$. The hydrolysis of urea can increase salivary $\mathrm{pH}$ through the formation of alkaline ammonia compounds, which cause 'uremic fetor' (a fish like odour on the breath on patients with renal failure) (Simenhoff et al., 1977, Epstein et al., 1980). An alkaline oral environment favours periodontal pathogens and their colonisation, and promotes calculus deposition (Ismail et al., 2015, Bots et al., 2006). Xerostomia, a dryness of the mouth and mucosal surfaces, is also a side effect in CKD patients, which is thought to be caused by a spectrum of factors such the changes in oral mucosa, reduced salivary flow and drugs used for CKD management (de la Rosa Garcia et al., 2006). The reduced flow of saliva in xerostomia has been shown to predispose patients to infections, gingival inflammation and the development of chronic periodontitis (de la Rosa Garcia et al., 2006, Kho et al., 1999, Porter et al., 2004). Intriguingly, CKD patients have a decreased incidence of caries, which is due to the alkaline oral environment not being amenable for cariogenic organisms (Peterson et al., 1985).

The persistent long-term increase of urea and uremic toxins (uremic toxaemia) has an effect on the immune system and can lead to immune dysregulation and chronic inflammation (Cohen and Hörl, 2012). Uremic toxins can cause a dysfunction of polymorphonuclear leukocytes (PLs) such as basophils, monocytes and neutrophils and dysregulate the innate immune response (Haag-Weber and Horl, 1996, Vaziri et al., 2012). Interestingly, previous studies have also shown that the ammonia produced by the degradation of the increased urea concentrations can inhibit neutrophil function which could result in an additive effect to the already dysregulated innate immune system (Niederman et al., 
1990). Such dysregulation in the innate immune system may lead to an increased risk of infection in the oral cavity, which can predispose $\mathrm{CKD}$ patients to $\mathrm{CP}$.

The drugs utilised for immunosuppressive therapy after transplantation (Calcinurin inhibitors) and calcium channel blockers, which are used to regulate the increased cytosolic calcium along with hypertension in those with renal disease, have also been reported to cause gingival hyperplasia (the overgrowth of the gingival tissue) in those with CKD (Somacarrera et al., 1994, Bharti and Bansal, 2013, Brown and Arany, 2015). Interestingly, this gingival overgrowth can be enhanced by poor oral hygiene which is reported to be particularly endemic in CKD patients and it has been suggested that such gingival overgrowth can lead to gingival inflammation and subsequent increased risk of CP (Reali et al., 2009, Pihlstrom et al., 2005).

Evidence suggests a multifactorial effect of the systemic consequences of CKD on the oral cavity, the result of which is the predisposition of CKD patients to CP (Figure 2). However, it should be noted that these mechanisms and their interactions need further investigation and there may be more complex interactions not yet elucidated. Indeed, there may be redundant pathways that still predispose to CP for example, while it was mentioned increased cytosolic calcium has been shown to cause dysfunction in immune cells, this can be treated to some extent by the calcium channel blockers which themselves induce gingival hyperplasia which can cause inflammation and predispose for $\mathrm{CP}$.

\subsection{Interactions between the Systemic Effects of CKD and CP}

The systemic and localised effects of CKD and CP and their impact on each other is difficult to elucidate, partly due to the complexity of the diseases but also because this is an under studied area. However, with careful consideration of the known systemic and localised effects of each disease, it is possible to suggest ways in which they may interact with each other. The potential interaction of the effects of CP (Section 3.1) and CKD (Section 3.2) is summarised (Figure 3) to hypothesize how these two diseases may lead to a potential bidirectional relationship.

The pathogenesis of CKD induces systemic inflammation and a more amenable environment in the oral cavity, which promotes the growth of periodontal pathogens. Furthermore, a dysfunction of the polymorphonuclear leukocytes would make the environment more amenable for the colonisation and persistence of periodontal pathogens (Rijkschroeff et al., 2016). Considered alone, these changes would predispose $\mathrm{CKD}$ patients to an increased risk of $\mathrm{CP}$, even without factoring in other known confounders such as age, smoking status and diseases such as diabetes. In addition, the establishment of $\mathrm{CP}$ has the potential to affect CKD due to the systemic inflammation produced along with the increased exposure to microorganisms and their products into the blood through persistent bacteraemia. With the kidneys playing a vital role in the body of filtration of the blood, it may cause bacterial products to affect renal cells, potentially leading to glomerular and/or tubular damage and fibrosis.

In CKD, the damage to the oral cavity (e.g. loss of teeth and gingival tissue) may also cause difficulties in the intake of food and medicine, and may be one of the contributing factors to the significant association of CKD and CP. The loss of teeth and gingiva may be accelerated in CKD by poor oral hygiene, as it has been shown that CKD patients access dental care less frequently (Grubbs et al., 2012). Furthermore, uremic patients are reported to be more prone to bacterial infections due to malnutrition (Mitch and Maroni, 1999), which impedes the production of antibodies and immune cells (De Rossi and Glick, 1996).

At this current moment in time, much of the evidence for a directional relationship (onset of exposure takes places before the outcome) between $\mathrm{CKD}$ and $\mathrm{CP}$, points in favour of $\mathrm{CKD}$ causing $\mathrm{CP}$ as there 
is less to support CP as a cause of CKD. However, current consensus suggest that it is more likely that there is a non-directional link (onset of the exposure can happen before, during or after the outcome) due to the lack of evidence currently available. Furthermore, while the evidence for the association between $\mathrm{CKD}$ and $\mathrm{CP}$ is plausible due to interaction of systemic effects alone, it would be prudent to investigate the effects of the organisms involved in periodontal disease and how they may directly affect CKD and the kidneys. This is especially important as periodontal organisms and their products have been shown to be directly involved in other systemic diseases, and there is evidence for oral microorganisms damaging the kidneys already in other microbial diseases. 
$\mathrm{CKD}$ and $\mathrm{CP}$ are both very common diseases in the general populace and have common risk factors such as malnutrition and inflammation, along with their presence being more pronounced in developingcountries (Van Dyke and Dave, 2005, Luyckx et al., 2017). As both diseases are highly prevalent independently of each other, it is to be expected that there would be some co-morbidity within patients. Indeed, it has been described that those patients whom have CKD have an increased prevalence of periodontitis compared to a geographically matched non-diseased population (Jha et al., 2013), with a systematic review of the relationship confirming this in multiple populations with an odds ratio of 1.65 (Chambrone et al., 2013). Furthermore, until recently the effect of CP on mortality rates was relatively unstudied with only small sized cohort studies over short durations. This has made accurate determination of mortality effects difficult as both diseases are multifactorial. Consequently, the evidence is contradictory with some studies reporting a detrimental effect (Linden et al., 2012, Chen et al., 2011) while other research suggests a more marginal effect (Avlund et al., 2009). However, a recent 10 year survival analysis of a large cohort of CKD patients found that the mortality rate increased from $32 \%$ to $41 \%$ when periodontitis existed (Sharma et al., 2016). This has also been confirmed by a meta-analysis of cohort studies which showed that periodontal disease was associated with an increased risk of death in CKD (Zhang et al., 2017). It is therefore plausible to suggest that CP increases the severity of $\mathrm{CKD}$ and as both $\mathrm{CKD}$ and $\mathrm{CP}$ are inflammatory mediated, this provides an avenue of enquiry to investigate.

As discussed in Section 3.3, CKD can affect the oral microenvironment with $\mathrm{pH}$ changes and gingival hyperplasia, making the environment more amenable for certain periodontal pathogens that thrive in a more alkaline environment (Listgarten, 1986). CP also effects CKD by increasing the systemic inflammation which is evident by increased C-reactive protein (Paraskevas et al., 2008). It is plausible that this could exacerbate systemic inflammation which is already present in CKD (Pihlstrom et al., 2005). Indeed, it is becoming more evident that the systemic inflammation induced by CP is a potential cause and/or non-traditional risk factor in the progression of CKD (Wahid et al., 2013). There have also been suggestions that there is a bidirectional relationship between $\mathrm{CKD}$ and $\mathrm{CP}$, with gingival tissue being a source of chronic inflammation and treatment of $\mathrm{CP}$ having a positive effect of glomerular filtration rate (Bastos et al., 2011, Fisher et al., 2011).

While the link between the two diseases is progressively strengthening, the mechanisms behind this relationship remain relatively unstudied. Much of the evidence reported for the mechanisms is purely observational through cohort studies and correlation, not resultant of a direct investigation. Furthermore, as the focal infection theory has been modernised to the periodontal medicine concept (Section 2), it is important to consider the potential ways in which these periodontal microorganisms might cause disease. It may not be as simple as a single causative mechanism; it is likely to be a summation of multiple mechanisms.

\section{Conclusion}

It has been reported for some time that there is a correlation between the presence of CKD and CP. However, while both diseases are associated with each other, the relationship between how they interact with regards to directionality is unclear. The effects of both diseases on the oral cavity and systemically, could be a plausible reason behind the perceived interactions, with effects based on inflammation and dysregulation of the immune system being common between the two. There is also 
a growing collection of evidence suggesting that oral microorganisms have the putative mechanisms to elicit a distal response in a multitude of diseases such as Alzheimer's disease and cardiovascular disease. Therefore, it would be prudent to investigate whether direct or microbial product translocation and dissemination could have a direct impact on the kidneys. It is clear that periodontal microorganisms can leave the oral cavity and cause disease at secondary sites such as the heart in infective endocarditis, and cause distal kidney damage without translocation as seen in acute post-streptococcal and infective endocarditis glomerulonephritis. This suggests that oral microorganisms may have multiple ways of causing damage in the kidneys, which complicates the potential involvement of these organisms and microbial products.

Attributing a directional or non-directional link association between both CKD and CP has been difficult for a variety of reasons. While there is growing evidence of a non-directional link between both diseases, evidence for directional interactions is limited due to the lack of studies and difficulties controlling for potential mitigating factors. The staging of CKD along with need for dialysis can have a stark difference on the outcomes of studies, and this is compounded by many other factors such as ethnicity, age and socioeconomic status. Concurrent conditions are particularly an issue for the study of chronic diseases with illnesses such as diabetes overlapping with CKD and CP and being implicated as a risk factor for both, highlighting the potential confounding effects. Indeed, a recent systemic review of the association between the two diseases reported that there was only supporting evidence for a non-directional link between the diseases (Zhao et al., 2018). This review also highlighted issues in many of the studies, such as differences in the definitions for both CKD and CP, low powered studies in non-representative groups and skewed focus on end stage renal disease patients, which was hindering the attribution of a directional link. With this in mind, further investigations are required to elucidate the reported role of CP in CKD; in particular as both diseases share common risk factors, it is important to use large and/or representative population groups with detailed reports on all potential confounders and a selection of different stages of CKD and severity of CP. Indeed, laboratory based investigations would also be very useful in order to investigate the effects of periodontal organisms at the biochemical and biofilm level rather than just cohort and cross sectional studies and whether they have the ability to directly influence CKD. As current research into CKD is focused around the identification of interventions or treatments to delay the progression of the disease particularly in the early stages, the putative influence of CP could provide a beneficial avenue to investigate.

In conclusion, there is a growing collection of evidence to support an association between CKD and $\mathrm{CP}$. However, understanding the directionality and causality behind the interactions of these two diseases is still unclear and requires further study. Despite some large cohort studies investigating CKD and $\mathrm{CP}$, it is particularly challenging to find a patient population without various other systemic diseases and mitigating factors that can be adjusted for confounding and derive a decisive conclusion. Nevertheless, the few exploratory studies looking at treatment of $\mathrm{CP}$ within $\mathrm{CKD}$ populations demonstrated that this intervention slowed the disease progression, highlighting a potentially novel and cost-effective approach for the future management of CKD. This could be instigated by ensuring better vigilance of the oral health status of those with $\mathrm{CKD}$. Further data from both laboratory and population based studies are eagerly awaited to further elucidate the interplay between $\mathrm{CKD}$ and $\mathrm{CP}$ and provide better understanding on how to treat these diseases.

\section{Geolocation}

Manchester, UK 


\section{$7 \quad$ Acknowledgements}

The authors wish to thank Emily Abrams-Cohen, Jacob Harrison and Jonathan Butler for their administrative support and proofreading.

\section{Disclosure Statement}

All authors declare that they have no conflict of interest.

\section{$9 \quad$ Funding}

This research did not receive any specific grant from funding agencies in the public, commercial, or not-for-profit sectors. 
ADDY, M. \& HUNTER, M. L. 2003. Can tooth brushing damage your health? Effects on oral and dental tissues. Int Dent J, 53 Suppl 3, 177-86.

ADEREM, A. \& ULEVITCH, R. J. 2000. Toll-like receptors in the induction of the innate immune response. Nature, 406, 782.

AHN, S. Y. \& INGULLI, E. 2008. Acute poststreptococcal glomerulonephritis: an update. Curr Opin Pediatr, 20, 157-62.

AITKEN, G. 2014. Analysis of estimates of CKD prevalence across England. In: ENGLAND, P. H. (ed.).

AKAR, H., AKAR, G. C., CARRERO, J. J., STENVINKEL, P. \& LINDHOLM, B. 2011. Systemic consequences of poor oral health in chronic kidney disease patients. Clin J Am Soc Nephrol, 6, 218-26.

AKPAN, A. \& MORGAN, R. 2002. Oral candidiasis. Postgraduate medical journal, 78, 455-459.

AL-HEBSHI, N. N., SHUGA-ALDIN, H. M., AL-SHARABI, A. K. \& GHANDOUR, I. 2014. Subgingival periodontal pathogens associated with chronic periodontitis in Yemenis. $B M C$ Oral Health, 14, 13-13.

ALBANDAR, J. M. \& KINGMAN, A. 1999. Gingival recession, gingival bleeding, and dental calculus in adults 30 years of age and older in the United States, 1988-1994. Journal of periodontology, 70, 30-43.

ALKJAERSIG, N. K., FLETCHER, A. P., LEWIS, M. L., COLE, B. R., INGELFINGER, J. R. \& ROBSON, A. M. 1976. Pathophysiological response of the blood coagulation system in acute glomerulonephritis. Kidney international, 10, 319-328.

ALMROTH, G., LINDELL, Å., ÅSELIUS, H., SÖRÉN, L., SVENSSON, L., HULTMAN, P., ERIBE, E. R. K. \& OLSEN, I. 2005. Acute Glomerulonephritis Associated with Streptococcus Pyogenes with Concomitant Spread of Streptococcus Constellatus in Four Rural Families. Upsala Journal of Medical Sciences, 110, 217-231.

AMBROSIONI, J., HERNANDEZ-MENESES, M., TELlEZ, A., PERICAS, J., FALCES, C., TOLOSANA, J. M., VIDAL, B., ALMELA, M., QUINTANA, E. \& LLOPIS, J. 2017. The changing epidemiology of infective endocarditis in the twenty-first century. Current infectious disease reports, 19, 21.

ANAND, N., S C, C. \& ALAM, M. N. 2013. The malnutrition inflammation complex syndrome-the micsing factor in the perio-chronic kidney disease interlink. J. Clin. Diagn. Res., 7, 763-767.

ARIYAMUTHU, V. K., NOLPH, K. D. \& RINGDAHL, B. E. 2013. Periodontal Disease in Chronic Kidney Disease and End-Stage Renal Disease Patients: A Review. Cardiorenal Medicine, 3, 71-78.

ARORA, N., MISHRA, A. \& CHUGH, S. 2014. Microbial role in periodontitis: Have we reached the top? Some unsung bacteria other than red complex. Journal of Indian Society of Periodontology, 18, 9-13.

AVLUND, K., SCHULTZ-LARSEN, K., KRUSTRUP, U., CHRISTIANSEN, N. \& HOLMPEDERSEN, P. 2009. Effect of inflammation in the periodontium in early old age on mortality at 21-year follow-up. J Am Geriatr Soc, 57, 1206-12. 
BADDOUR, L. M., WILSON, W. R., BAYER, A. S., FOWLER, V. G., TLEYJEH, I. M., RYBAK, M. J., BARSIC, B., LOCKHART, P. B., GEWITZ, M. H. \& LEVISON, M. E. 2015. Infective endocarditis in adults: diagnosis, antimicrobial therapy, and management of complications. Circulation, 132, 1435-1486.

BASTOS, J. A., DINIZ, C. G., BASTOS, M. G., VILELA, E. M., SILVA, V. L., CHAOUBAH, A., SOUZA-COSTA, D. C. \& ANDRADE, L. C. F. 2011. Identification of periodontal pathogens and severity of periodontitis in patients with and without chronic kidney disease. Archives of Oral Biology, 56, 804-811.

BAYER, A. S. \& THEOFILOPOULOS, A. N. 1990. Immunopathogenetic aspects of infective endocarditis. Chest, 97, 204-12.

BECK, J. D., MOSS, K. L., MORELLI, T. \& OFFENBACHER, S. 2018. Periodontal profile class is associated with prevalent diabetes, coronary heart disease, stroke, and systemic markers of Creactive protein and interleukin-6. J Periodontol, 89, 157-165.

BHARTI, V. \& BANSAL, C. 2013. Drug-induced gingival overgrowth: The nemesis of gingiva unravelled. J Indian Soc Periodontol, 17, 182-7.

BILLINGS, F. 1916. Focal infection, D. Appleton.

BOILS, C. L., NASR, S. H., WALKER, P. D., COUSER, W. G. \& LARSEN, C. P. 2015. Update on endocarditis-associated glomerulonephritis. Kidney International, 87, 1241-1249.

BORAWSKI, J., WILCZYŃSKA-BORAWSKA, M., STOKOWSKA, W. \& MYŚLIWIEC, M. 2006. The periodontal status of pre-dialysis chronic kidney disease and maintenance dialysis patients. Nephrol. Dial. Transplant., 22, 457-464.

BOSSHARDT, D. D. 2017. The periodontal pocket: pathogenesis, histopathology and consequences. Periodontology 2000.

BOTS, C. P., POORTERMAN, J. H., BRAND, H. S., KALSBEEK, H., VAN AMERONGEN, B. M., VEERMAN, E. C. \& NIEUW AMERONGEN, A. V. 2006. The oral health status of dentate patients with chronic renal failure undergoing dialysis therapy. Oral Dis, 12, 176-80.

BRODSKY, S. V. \& NADASDY, T. 2017. Acute Poststreptococcal Glomerulonephritis. In: SATOSKAR, A. A. \& NADASDY, T. (eds.) Bacterial Infections and the Kidney. Cham: Springer International Publishing.

BROWN, R. S. \& ARANY, P. R. 2015. Mechanism of drug-induced gingival overgrowth revisited: a unifying hypothesis. Oral Dis, 21, e51-61.

BYRNE, S. J., DASHPER, S. G., DARBY, I. B., ADAMS, G. G., HOFFMANN, B. \& REYNOLDS, E. C. 2009. Progression of chronic periodontitis can be predicted by the levels of Porphyromonas gingivalis and Treponema denticola in subgingival plaque. Oral Microbiol Immunol, 24, 469-77.

CABELL, C. H., ABRUTYN, E. \& KARCHMER, A. W. 2003. Bacterial endocarditis. Circulation, 107, e185-e187.

CARAPETIS, J. R., STEER, A. C., MULHOLLAND, E. K. \& WEBER, M. 2005. The global burden of group A streptococcal diseases. Lancet Infect Dis, 5, 685-694.

CARMONA, I. T., DIOS, P. D. \& SCULLY, C. 2002. An update on the controversies in bacterial endocarditis of oral origin. Oral Surgery, Oral Medicine, Oral Pathology, Oral Radiology and Endodontics, 93, 660-670. 
CATON, J. G., ARMITAGE, G., BERGLUNDH, T., CHAPPLE, I. L., JEPSEN, S., KORNMAN, K. S., MEALEY, B. L., PAPAPANOU, P. N., SANZ, M. \& TONETTI, M. S. 2018. A new classification scheme for periodontal and peri-implant diseases and conditions-Introduction and key changes from the 1999 classification. Journal of periodontology, 89, S1-S8.

CHAMBrone, L., FOZ, A. M., GUGlielmetti, M. R., PANNUTI, C. M., ARTESE, H. P. C., FERES, M. \& ROMITO, G. A. 2013. Periodontitis and chronic kidney disease: a systematic review of the association of diseases and the effect of periodontal treatment on estimated glomerular filtration rate. Journal of Clinical Periodontology, 40, 443-456.

CHEN, L.-P., CHIANG, C.-K., CHAN, C.-P., HUNG, K.-Y. \& HUANG, C.-S. 2006. Does periodontitis reflect inflammation and malnutrition status in hemodialysis patients? American journal of kidney diseases, 47, 815-822.

CHEN, L. P., CHIANG, C. K., PENG, Y. S., HSU, S. P., LIN, C. Y., LAI, C. F. \& HUNG, K. Y. 2011. Relationship between periodontal disease and mortality in patients treated with maintenance hemodialysis. Am J Kidney Dis, 57, 276-82.

COHEN, G. \& HÖRL, W. H. 2012. Immune dysfunction in uremia-an update. Toxins, 4, 962-990.

CORESH, J. 2017. Update on the Burden of CKD. Journal of the American Society of Nephrology, 28, 1020-1022.

COUSER, W. G., REMUZZI, G., MENDIS, S. \& TONELLI, M. 2011. The contribution of chronic kidney disease to the global burden of major noncommunicable diseases. Kidney international, 80, 1258-1270.

COYKENDALL, A. L. 1989. Classification and identification of the viridans streptococci. Clinical Microbiology Reviews, 2, 315-328.

CRAIG, R. G. 2008. Interactions between chronic renal disease and periodontal disease. Oral Dis, $14,1-7$.

CRONIN, W., DEOL, H., AZADEGAN, A. \& LANGE, K. 1989. Endostreptosin: isolation of the probable immunogen of acute post-streptococcal glomerulonephritis (PSGN). Clinical and Experimental Immunology, 76, 198-203.

DARVEAU, R. P. 2010. Periodontitis: a polymicrobial disruption of host homeostasis. Nat Rev Microbiol, 8, 481-90.

DASHPER, S. G., SEERS, C. A., TAN, K. H. \& REYNOLDS, E. C. 2011. Virulence factors of the oral spirochete Treponema denticola. Journal of dental research, 90, 691-703.

DE LA ROSA GARCIA, E., MONDRAGON PADILLA, A., ARANDA ROMO, S. \& BUSTAMANTE RAMIREZ, M. A. 2006. Oral mucosa symptoms, signs and lesions, in end stage renal disease and non-end stage renal disease diabetic patients. Med Oral Patol Oral Cir Bucal, 11, E467-73.

DE ROSSI, S. S. \& GLICK, M. 1996. Dental considerations for the patient with renal disease receiving hemodialysis. J Am Dent Assoc, 127, 211-9.

DESHPANDE, R. G., KHAN, M. B. \& GENCO, C. A. 1998. Invasion of aortic and heart endothelial cells by Porphyromonas gingivalis. Infect Immun, 66, 5337-43.

DEWHIRST, F. E., CHEN, T., IZARD, J., PASTER, B. J., TANNER, A. C. R., YU, W.-H., LAKSHMANAN, A. \& WADE, W. G. 2010. The human oral microbiome. Journal of bacteriology, 192, 5002-5017. 
DHONDUP, T. \& QIAN, Q. 2017. Electrolyte and Acid-Base Disorders in Chronic Kidney Disease and End-Stage Kidney Failure. Blood Purification, 43, 179-188.

DIETRICH, T., JIMENEZ, M., KRALL KAYE, E. A., VOKONAS, P. S. \& GARCIA, R. I. 2008. Age-Dependent Associations Between Chronic Periodontitis/Edentulism and Risk of Coronary Heart Disease. Circulation, 117, 1668.

DOMINY, S. S., LYNCH, C., ERMINI, F., BENEDYK, M., MARCZYK, A., KONRADI, A., NGUYEN, M., HADITSCH, U., RAHA, D. \& GRIFFIN, C. 2019. Porphyromonas gingivalis in Alzheimer's disease brains: Evidence for disease causation and treatment with smallmolecule inhibitors. Science advances, 5, eaau3333.

DYCK, R. F., HAYWARD, M. N. \& HARRIS, S. B. 2012. Prevalence, determinants and comorbidities of chronic kidney disease among First Nations adults with diabetes: results from the CIRCLE study. BMC nephrology, 13, 57.

DYE, B. A., CHOUDHARY, K., SHEA, S. \& PAPAPANOU, P. N. 2005. Serum antibodies to periodontal pathogens and markers of systemic inflammation. J Clin Periodontol, 32, 118999.

EARLE, D. P. 1985. Poststreptococcal acute glomerulonephritis. Hospital Practice, 20, 84E-84BB.

EDGAR, W. M., O'MULLANE, D. M. \& DAWES, C. 2004. Saliva and oral health, British Dental Association London.

ENGEBRETSON, S. P., HYMAN, L. G., MICHALOWICZ, B. S. \& ET AL. 2013. The effect of nonsurgical periodontal therapy on hemoglobin a1c levels in persons with type 2 diabetes and chronic periodontitis: A randomized clinical trial. JAMA, 310, 2523-2532.

EPSTEIN, S. R., MANDEL, I. \& SCOPP, I. W. 1980. Salivary composition and calculus formation in patients undergoing hemodialysis. J Periodontol, 51, 336-8.

EVERETT, E. D. \& HIRSCHMANN, J. V. 1977. Transient bacteremia and endocarditis prophylaxis. A review. Medicine, 56, 61-77.

FINN, W. F. 1977a. Renal response to environmental toxics. Environmental health perspectives, 20, 15.

FINN, W. F. 1977b. Renal response to environmental toxins. Environ Health Perspect, 20, 15-26.

FISHER, M. A., BORGNAKKE, W. S. \& TAYLOR, G. W. 2010. Periodontal disease as a risk marker in coronary heart disease and chronic kidney disease. Current opinion in nephrology and hypertension, 19, 519-526.

FISHER, M. A., TAYLOR, G. W., WEST, B. T. \& MCCARTHY, E. T. 2011. Bidirectional relationship between chronic kidney and periodontal disease: a study using structural equation modeling. Kidney Int, 79, 347-55.

FLEMMIG, T. F. 1999. Periodontitis. Ann Periodontol, 4, 32-8.

FRENCKEN, J. E., SHARMA, P., STENHOUSE, L., GREEN, D., LAVERTY, D. \& DIETRICH, T. 2017. Global epidemiology of dental caries and severe periodontitis-a comprehensive review. Journal of clinical periodontology, 44, S94-S105.

FUKUI, K., KATO, N., KATO, H., WATANABE, K. \& TATEMATSU, N. 1999. Incidence of Prevotella intermedia and Prevotella nigrescens Carriage among Family Members with Subclinical Periodontal Disease. Journal of Clinical Microbiology, 37, 3141-3145. 
GENDRON, R., GRENIER, D. \& MAHEU-ROBERT, L.-F. 2000. The oral cavity as a reservoir of bacterial pathogens for focal infections. Microbes and infection, 2, 897-906.

GERMAN, R. Z. \& PALMER, J. B. 2006. Anatomy and development of oral cavity and pharynx. GI Mot. On.

GRUBBS, V., PLANTINGA, L. C., TUOT, D. S. \& POWE, N. R. 2012. Chronic kidney disease and use of dental services in a United States public healthcare system: a retrospective cohort study. BMC Nephrol, 13, 16.

GUALTERO, D. F., LAFAURIE, G. I. \& FONTANILLA, M. R. 2018. Two-dimensional and threedimensional models for studying atherosclerosis pathogenesis induced by periodontopathogenic microorganisms. Mol Oral Microbiol, 33, 29-37.

GUAN, S. M., SHU, L., FU, S. M., LIU, B., XU, X. L. \& WU, J. Z. 2008. Prevotella intermedia induces matrix metalloproteinase- 9 expression in human periodontal ligament cells. FEMS Microbiol Lett, 283, 47-53.

HAAG-WEBER, M. \& HORL, W. H. 1996. Dysfunction of polymorphonuclear leukocytes in uremia. Semin Nephrol, 16, 192-201.

HAFFAJEE, A. D., TELES, R. P. \& SOCRANSKY, S. S. 2006. Association of Eubacterium nodatum and Treponema denticola with human periodontitis lesions. Oral Microbiology and Immunology, 21, 269-282.

HAJISHENGALLIS, G. 2009. Porphyromonas gingivalis-host interactions: open war or intelligent guerilla tactics? Microbes Infect, 11, 637-45.

HAJISHENGALLIS, G. 2015. Periodontitis: from microbial immune subversion to systemic inflammation. Nat. Rev. Immunol., 15, 30-44.

HAJISHENGALLIS, G. \& LAMONT, R. J. 2012. Beyond the red complex and into more complexity: the polymicrobial synergy and dysbiosis (PSD) model of periodontal disease etiology. Mol Oral Microbiol, 27, 409-19.

HAMER, R. A. \& EL NAHAS, A. M. 2006. The burden of chronic kidney disease: is rising rapidly worldwide. BMJ, 332, 563.

HAN, Y. W., REDLINE, R. W., LI, M., YIN, L., HILL, G. B. \& MCCORMICK, T. S. 2004. Fusobacterium nucleatum induces premature and term stillbirths in pregnant mice: implication of oral bacteria in preterm birth. Infection and immunity, 72, 2272-2279.

HEIDARI, E., BANERJEE, A. \& NEWTON, J. T. 2015. Oral health status of non-phobic and dentally phobic individuals; a secondary analysis of the 2009 Adult Dental Health Survey. $\mathrm{Br}$ Dent J, 219, E9.

HEMMELGARN, B. R., MANNS, B. J., LLOYD, A., JAMES, M. T., KLARENBACH, S., QUINN, R. R., WIEBE, N., TONELLI, M. \& ALBERTA KIDNEY DISEASE, N. 2010. Relation between kidney function, proteinuria, and adverse outcomes. Jama, 303, 423-429.

HENDERSON, B., WARD, J. M. \& READY, D. 2010. Aggregatibacter (Actinobacillus) actinomycetemcomitans: a triple A* periodontopathogen? Periodontol 2000, 54, 78-105.

HENDRICKSON, E. L., BECK, D. A. C., MILlER, D. P., WANG, Q., WHITELEY, M., LAMONT, R. J. \& HACKETT, M. 2017. Insights into Dynamic Polymicrobial Synergy Revealed by Time-Coursed RNA-Seq. Frontiers in Microbiology, 8, 261. 
HONARMAND, M., FARHAD-MOLLASHAHI, L., NAKHAEE, A. \& SARGOLZAIE, F. 2017. Oral manifestation and salivary changes in renal patients undergoing hemodialysis. $J$ Clin Exp Dent, 9, e207-e210.

HOY, W. E., HUGHSON, M. D., BERTRAM, J. F., DOUGLAS-DENTON, R. \& AMANN, K. 2005. Nephron number, hypertension, renal disease, and renal failure. Journal of the American Society of Nephrology, 16, 2557-2564.

HRUSKA, K. A., MATHEW, S., LUND, R., QIU, P. \& PRATT, R. 2008. Hyperphosphatemia of chronic kidney disease. Kidney International, 74, 148-157.

INKER, L. A., ASTOR, B. C., FOX, C. H., ISAKOVA, T., LASH, J. P., PERALTA, C. A., KURELLA TAMURA, M. \& FELDMAN, H. I. KDOQI US Commentary on the 2012 KDIGO Clinical Practice Guideline for the Evaluation and Management of CKD. AJKD, 63, 713-735.

INKER, L. A. \& LEVEY, A. S. 2014. 53 - Staging and Management of Chronic Kidney Disease. In: GILBERT, S. J. \& WEINER, D. E. (eds.) National Kidney Foundation Primer on Kidney Diseases (Sixth Edition). Philadelphia: W.B. Saunders.

ISHIKAWA, M., YOSHIDA, K., OKAMURA, H., OCHIAI, K., TAKAMURA, H., FUJIWARA, N. \& OZAKI, K. 2013. Oral Porphyromonas gingivalis translocates to the liver and regulates hepatic glycogen synthesis through the Akt/GSK-3 $\beta$ signaling pathway. Biochim. Biophys. Acta 1832, 2035-2043.

ISMAIL, F. B., ISMAIL, G., DUMITRIU, A. S., BASTON, C., BERBECAR, V., JURUBITA, R., ANDRONESI, A., DUMITRIU, H. T. \& SINESCU, I. 2015. Identification of subgingival periodontal pathogens and association with the severity of periodontitis in patients with chronic kidney diseases: a cross-sectional study. Biomed Res. Int., 2015, 370314.

JAMESON, J. L. \& LOSCALZO, J. 2016. Harrison's Nephrology and Acid-Base Disorders, 3e, McGraw-Hill Education.

JAWETZ, M. 2007. Adelberg's Medical microbiology. Antibacterial and Antifungal chemotherapy (Prentice-Hall International Inc).

JHA, V., GARCIA-GARCIA, G., ISEKI, K., LI, Z., NAICKER, S., PLATTNER, B., SARAN, R., WANG, A. Y.-M. \& YANG, C.-W. 2013. Chronic kidney disease: global dimension and perspectives. The Lancet, 382, 260-272.

JONES, R. 2010. Chronic disease and comorbidity. Br J Gen Pract, 60, 394-394.

JUDD, E. \& CALHOUN, D. A. 2015. Management of hypertension in CKD: beyond the guidelines. Adv Chronic Kidney Dis, 22, 116-22.

KALANTAR-ZADEH, K., SHAH, A., DUONG, U., HECHTER, R. C., DUKKIPATI, R. \& KOVESDY, C. P. 2010. Kidney bone disease and mortality in CKD: revisiting the role of vitamin D, calcimimetics, alkaline phosphatase, and minerals. Kidney International, 78, S10S21.

KASSEBAUM, N. J., SMITH, A. G. C., BERNABE, E., FLEMING, T. D., REYNOLDS, A. E., VOS, T., MURRAY, C. J. L. \& MARCENES, W. 2017. Global, Regional, and National Prevalence, Incidence, and Disability-Adjusted Life Years for Oral Conditions for 195 Countries, 1990-2015: A Systematic Analysis for the Global Burden of Diseases, Injuries, and Risk Factors. J Dent Res, 96, 380-387. 
KATZ, J., CHEGINI, N., SHIVERICK, K. T. \& LAMONT, R. J. 2009. Localization of

Porphyromonas gingivalis in preterm delivery placenta. J Dent Res, 88, 575-8.

KAZANCIOGLU, R. 2013. Risk factors for chronic kidney disease: an update. Kidney Int Suppl (2011), 3, 368-371.

KESAVALU, L., SATHISHKUMAR, S., BAKTHAVATCHALU, V., MATTHEWS, C., DAWSON, D., STEFFEN, M. \& EBERSOLE, J. L. 2007. Rat model of polymicrobial infection, immunity, and alveolar bone resorption in periodontal disease. Infect Immun, 75, 1704-12.

KHO, H.-S., LEE, S.-W., CHUNG, S.-C. \& KIM, Y.-K. 1999. Oral manifestations and salivary flow rate, $\mathrm{pH}$, and buffer capacity in patients with end-stage renal disease undergoing hemodialysis. Oral Surg. Oral Med. Oral Pathol. Oral Radiol., 88, 316-319.

KÖNÖNEN, E. \& WADE, W. G. 2015. Actinomyces and Related Organisms in Human Infections. Clinical Microbiology Reviews, 28, 419-442.

KUMAR, M., UMASHANKAR, D. N., VISWANATH, D. \& GIRISH, G. 2013. Role of the Oral Microflora in Health and Disease. JIAOMR, 25, 184-187.

LEVEY, A. S., CORESH, J., BALK, E. \& ET AL. 2003. National kidney foundation practice guidelines for chronic kidney disease: Evaluation, classification, and stratification. Annals of Internal Medicine, 139, 137-147.

LI, X., KOLLTVEIT, K. M., TRONSTAD, L. \& OLSEN, I. 2000. Systemic diseases caused by oral infection. Clinical microbiology reviews, 13, 547-558.

LINDEN, G. J., LINDEN, K., YARNELL, J., EVANS, A., KEE, F. \& PATTERSON, C. C. 2012. All-cause mortality and periodontitis in 60-70-year-old men: a prospective cohort study. $J$ Clin Periodontol, 39, 940-6.

LISTGARTEN, M. A. 1986. Pathogenesis of periodontitis. J Clin Periodontol, 13.

LOOS, B. G. 2005. Systemic markers of inflammation in periodontitis. Journal of periodontology, 76, 2106-2115.

LOOS, B. G. 2006. Systemic effects of periodontitis. International journal of dental hygiene, 4, 3438.

LUSCO, M. A., FOGO, A. B., NAJAFIAN, B. \& ALPERS, C. E. 2016. AJKD Atlas of Renal Pathology: Subacute Bacterial Endocarditis-Associated Glomerulonephritis. American Journal of Kidney Diseases, 68, e11-e12.

LUYCKX, V. A., TUTTLE, K. R., GARCIA-GARCIA, G., GHARBI, M. B., HEERSPINK, H. J. L., JOHNSON, D. W., LIU, Z.-H., MASSY, Z. A., MOE, O., NELSON, R. G., SOLA, L., WHEELER, D. C. \& WHITE, S. L. 2017. Reducing major risk factors for chronic kidney disease. Kidney Int. Suppl., 7, 71-87.

MACUCH, P. J. \& TANNER, A. C. 2000. Campylobacter species in health, gingivitis, and periodontitis. J Dent Res, 79, 785-92.

MAJUMDAR, A., CHOWDHARY, S., FERREIRA, M. A., HAMMOND, L. A., HOWIE, A. J., LIPKIN, G. W. \& LITTLER, W. A. 2000. Renal pathological findings in infective endocarditis. Nephrol. Dial. Transplant., 15, 1782-1787.

MARSH, P. D. 1994. Microbial ecology of dental plaque and its significance in health and disease. Advances in dental research, 8, 263-271. 
MARSH, P. D. 2000. Role of the oral microflora in health. Microbial Ecology in Health and Disease, $12,130-137$.

MARSH, P. D., MARTIN, M. V., LEWIS, M. A. O. \& WILLIAMS, D. 2009. Oral Microbiology EBook, Elsevier health sciences.

MEYER, T. W. \& HOSTETTER, T. H. 2007. Uremia. New England Journal of Medicine, 357, 1316-1325.

MILLER, W. D. 1891. The human mouth as a focus of infection. The Lancet, 138, 340-342.

MIRRAKHIMOV, A. E. 2012. Obstructive sleep apnea and kidney disease: is there any direct link? Sleep Breath, 16, 1009-16.

MITCH, W. E. \& MARONI, B. J. 1999. Factors causing malnutrition in patients with chronic uremia. Am J Kidney Dis, 33, 176-9.

MOUTSOPOULOS, N. M. \& MADIANOS, P. N. 2006. Low-grade inflammation in chronic infectious diseases: paradigm of periodontal infections. Ann N Y Acad Sci, 1088, 251-64.

NASR, S. H., FIDLER, M. E., VALERI, A. M., CORNELL, L. D., SETHI, S., ZOLLER, A., STOKES, M. B., MARKOWITZ, G. S. \& D'AGATI, V. D. 2011. Postinfectious glomerulonephritis in the elderly. Journal of the American Society of Nephrology, 22, 187195.

NASR, S. H., MARKOWITZ, G. S., STOKES, M. B., SAID, S. M., VALERI, A. M. \& D'AGATI, V. D. 2008. Acute postinfectious glomerulonephritis in the modern era: experience with 86 adults and review of the literature. Medicine, 87, 21-32.

NIEDERMAN, R., BRUNKHORST, B., SMITH, S., WEINREB, R. N. \& RYDER, M. I. 1990. Ammonia as a potential mediator of adult human periodontal infection: inhibition of neutrophil function. Arch Oral Biol, 35 Suppl, 205s-209s.

NOGUEIRA, A., PIRES, M. J. \& OLIVEIRA, P. A. 2017. Pathophysiological mechanisms of renal fibrosis: a review of animal models and therapeutic strategies. in vivo, 31, 1-22.

OBANDO-PEREDA, G. 2018. Trojans in Oral Environments: Evidence of Molecular Mimicry in Oral Immunity. Oral Microbiology in Periodontitis. IntechOpen.

OBERG, B. P., MCMENAMIN, E., LUCAS, F., MCMONAGLE, E., MORROW, J., IKIZLER, T. \& HIMMELFARB, J. 2004. Increased prevalence of oxidant stress and inflammation in patients with moderate to severe chronic kidney disease. Kidney international, 65, 1009-1016.

OHKUNI, H., FRIEDMAN, J., VAN DE RIJN, I., FISCHETTI, V. A., POON-KING, T. \& ZABRISKIE, J. B. 1983. Immunological studies of post-streptococcal sequelae: serological studies with an extracellular protein associated with nephritogenic streptococci. Clinical and experimental immunology, 54, 185.

OLSEN, I. \& YAMAZAKI, K. 2019. Can oral bacteria affect the microbiome of the gut? Journal of oral microbiology, 11, 1586422.

OYETOLA, E. O., OWOTADE, F. J., AGBELUSI, G. A., FATUSI, O. A. \& SANUSI, A. A. 2015. Oral findings in chronic kidney disease: implications for management in developing countries. BMC Oral Health, 15, 24.

PADILlA, C., LOBOS, O., HUBERT, E., GONZALEZ, C., MATUS, S., PEREIRA, M., HASBUN, S. \& DESCOUVIERES, C. 2006. Periodontal pathogens in atheromatous plaques isolated from patients with chronic periodontitis. J Periodontal Res, 41, 350-3. 
PAPAPANOU, P., SANZ, M., BUDUNELI, N., DIETRICH, T., FERES, M., FINE, D., FLEMMIG, T., GARCIA, R., GIANNOBILE, W. \& GRAZIANI, F. 2018. Periodontitis. Journal of Periodontology, 89.

PARASKEVAS, S., HUIZINGA, J. D. \& LOOS, B. G. 2008. A systematic review and meta-analyses on C-reactive protein in relation to periodontitis. Journal of Clinical Periodontology, 35, 277290.

PAYNE, M., HASHIM, A., ALSAM, A., JOSEPH, S., ADUSE-OPOKU, J., WADE, W. \& CURTIS, M. 2019. Horizontal and Vertical Transfer of Oral Microbial Dysbiosis and Periodontal Disease. Journal of Dental Research, 0022034519877150.

PETERSON, S., WOODHEAD, J. \& CRALL, J. 1985. Caries resistance in children with chronic renal failure: plaque $\mathrm{pH}$, salivary $\mathrm{pH}$, and salivary composition. Pediatric research, 19, 796.

PIHLSTROM, B. L., MICHALOWICZ, B. S. \& JOHNSON, N. W. 2005. Periodontal diseases. The Lancet, 366, 1809-1820.

PIZZO, G., GUIGLIA, R., RUSSO, L. L. \& CAMPISI, G. 2010. Dentistry and internal medicine: from the focal infection theory to the periodontal medicine concept. European journal of internal medicine, 21, 496-502.

PORTER, S. R., SCULLY, C. \& HEGARTY, A. M. 2004. An update of the etiology and management of xerostomia. Oral Surg Oral Med Oral Pathol Oral Radiol Endod, 97, 28-46.

POVEDA-RODA, R., JIMENEZ, Y., CARBONELL, E., GAVALDA, C., MARGAIX-MUNOZ, M. M. \& SARRIÓN-PÉREZ, G. 2008. Bacteremia originating in the oral cavity. A review. Medicina oral, patologia oral y cirugia bucal, 13, E355-62.

PRADEEP, A. R., KATHARIYA, R., ARJUN RAJU, P., SUSHMA RANI, R., SHARMA, A. \& RAGHAVENDRA, N. M. 2012. Risk factors for chronic kidney diseases may include periodontal diseases, as estimated by the correlations of plasma pentraxin-3 levels: a casecontrol study. Int Urol Nephrol, 44, 829-39.

PRESHAW, P., ALBA, A., HERRERA, D., JEPSEN, S., KONSTANTINIDIS, A., MAKRILAKIS, K. \& TAYLOR, R. 2012. Periodontitis and diabetes: a two-way relationship. Diabetologia, $55,21-31$.

RAMANATHAN, G., ABEYARATNE, A., SUNDARAM, M., FERNANDES, D. K., PAWAR, B., PERRY, G. J., SAJIV, C. \& MAJONI, S. W. 2017. Analysis of clinical presentation, pathological spectra, treatment and outcomes of biopsy-proven acute postinfectious glomerulonephritis in adult indigenous people of the Northern Territory of Australia. Nephrology, 22, 403-411.

RAMS, T. E., FEIK, D., MORTENSEN, J. E., DEGENER, J. E. \& WINKELHOFF, A. J. 2014. Antibiotic susceptibility of periodontal Streptococcus constellatus and Streptococcus intermedius clinical isolates. Journal of periodontology, 85, 1792-1798.

RASIAH, I. A., WONG, L., ANDERSON, S. A. \& SISSONS, C. H. 2005. Variation in bacterial DGGE patterns from human saliva: over time, between individuals and in corresponding dental plaque microcosms. Archives of Oral Biology, 50, 779-787.

REALI, L., ZULIANI, E., GABUTTI, L., SCHÖNHOLZER, C. \& MARONE, C. 2009. Poor oral hygiene enhances gingival overgrowth caused by calcineurin inhibitors. Journal of clinical pharmacy and therapeutics, 34, 255-260. 
RIJKSCHROEFF, P., JANSEN, I. D. C., VAN DER WEIJDEN, F. A., KEIJSER, B. J. F., LOOS, B. G. \& NICU, E. A. 2016. Oral polymorphonuclear neutrophil characteristics in relation to oral health: a cross-sectional, observational clinical study. Int. J. Oral Sci., 8, 191-198.

SALGADO-PABON, W., BRESHEARS, L., SPAULDING, A. R., MERRIMAN, J. A., STACH, C. S., HORSWILL, A. R., PETERSON, M. L. \& SCHLIEVERT, P. M. 2013. Superantigens are critical for Staphylococcus aureus Infective endocarditis, sepsis, and acute kidney injury. MBio, 4.

SCANNAPIECO, F. A. 1998. Position paper of The American Academy of Periodontology: periodontal disease as a potential risk factor for systemic diseases. Journal of periodontology, 69, 841-850.

SCHATZLE, M., LOE, H., LANG, N. P., BURGIN, W., ANERUD, A. \& BOYSEN, H. 2004. The clinical course of chronic periodontitis. J Clin Periodontol, 31, 1122-7.

SCHELD, W. M., VALONE, J. A. \& SANDE, M. A. 1978. Bacterial adherence in the pathogenesis of endocarditis. Interaction of bacterial dextran, platelets, and fibrin. J. Clin. Invest., 61, 13941404.

SCHELLEVIS, F. G., VAN DER VELDEN, J., VAN DE LISDONK, E., VAN EIJK, J. T. M. \& VAN WEEL, C. 1993. Comorbidity of chronic diseases in general practice. Journal of Clinical Epidemiology, 46, 469-473.

SEN, S., GIAMBERARDINO, L. D., MOSS, K., MORELLI, T., ROSAMOND, W. D., GOTTESMAN, R. F., BECK, J. \& OFFENBACHER, S. 2018. Periodontal Disease, Regular Dental Care Use, and Incident Ischemic Stroke. Stroke, 49, 355-362.

SERRA E SILVA FILHO, W., CASARIN, R. C., NICOLELA, E. L., JR., PASSOS, H. M., SALLUM, A. W. \& GONCALVES, R. B. 2014. Microbial diversity similarities in periodontal pockets and atheromatous plaques of cardiovascular disease patients. PLoS One, 9, e109761.

SETTEM, R. P., EL-HASSAN, A. T., HONMA, K., STAFFORD, G. P. \& SHARMA, A. 2012. Fusobacterium nucleatum and Tannerella forsythia Induce Synergistic Alveolar Bone Loss in a Mouse Periodontitis Model. Infection and Immunity, 80, 2436-2443.

SEYMOUR, G. J., FORD, P. J., CULLINAN, M. P., LEISHMAN, S. \& YAMAZAKI, K. 2007. Relationship between periodontal infections and systemic disease. Clinical Microbiology and Infection, 13, 3-10.

SHAIKH, H. F. M., PATIL, S. H., PANGAM, T. S. \& RATHOD, K. V. 2018. Polymicrobial synergy and dysbiosis: An overview. Journal of Indian Society of Periodontology, 22, 101106.

SHARMA, P., DIETRICH, T., FERRO, C. J., COCKWELL, P. \& CHAPPLE, I. L. C. 2016. Association between periodontitis and mortality in stages 3-5 chronic kidney disease: NHANES III and linked mortality study. Journal of Clinical Periodontology, 43, 104-113.

SHI, Y., LIU, Z., SHEN, Y. \& ZHU, H. 2018. A Novel Perspective Linkage Between Kidney Function and Alzheimer's Disease. Frontiers in cellular neuroscience, 12, 384-384.

SIMENHOFF, M. L., BURKE, J. F., SAUKKONEN, J. J., ORDINARIO, A. T., DOTY, R. \& DUNN, S. 1977. Biochemical profile of uremic breath. New England Journal of Medicine, 297, 132-135. 
SLADE, G. D., GHEZZI, E. M., HEISS, G., BECK, J. D., RICHE, E. \& OFFENBACHER, S. 2003. Relationship between periodontal disease and C-reactive protein among adults in the Atherosclerosis Risk in Communities study. Archives of internal medicine, 163, 1172-1179.

SMALLEY, J. 1994. Pathogenic mechanisms in periodontal disease. Advances in dental research, 8, 320-328.

SOCRANSKY, S., HAFFAJEE, A., CUGINI, M., SMITH, C. \& KENT JR, R. 1998. Microbial complexes in subgingival plaque. Journal of clinical periodontology, 25, 134-144.

SOMACARRERA, M. L., HERNANDEZ, G., ACERO, J. \& MOSKOW, B. S. 1994. Factors related to the incidence and severity of cyclosporin-induced gingival overgrowth in transplant patients. A longitudinal study. J Periodontol, 65, 671-5.

STINGU, C. S., SCHAUMANN, R., JENTSCH, H., ESCHRICH, K., BROSTEANU, O. \& RODLOFF, A. C. 2013. Association of periodontitis with increased colonization by Prevotella nigrescens. J. Investig. Clin. Dent., 4, 20-5.

TADA, A. \& HANADA, N. 2010. Opportunistic respiratory pathogens in the oral cavity of the elderly. FEMS Immunology \& Medical Microbiology, 60, 1-17.

TANAKA, S., YOSHIDA, M., MURAKAMI, Y., OGIWARA, T., SHOJI, M., KOBAYASHI, S., WATANABE, S., MACHINO, M. \& FUJISAWA, S. 2008. The relationship of Prevotella intermedia, Prevotella nigrescens and Prevotella melaninogenica in the supragingival plaque of children, caries and oral malodor. J. Clin. Pediatr. Dent., 32, 195-200.

TAYLOR, J. J. \& PRESHAW, P. M. 2016. Gingival crevicular fluid and saliva. Periodontol 2000, 70, 7-10.

THODEN VAN VELZEN, S. K., ABRAHAM-INPIJN, L. \& MOORER, W. R. 1984. Plaque and systemic disease: a reappraisal of the focal infection concept. J Clin Periodontol, 11, 209-20.

TONELLI, M., WIEBE, N., GUTHRIE, B., JAMES, M. T., QUAN, H., FORTIN, M., KLARENBACH, S. W., SARGIOUS, P., STRAUS, S., LEWANCZUK, R., RONKSLEY, P. E., MANNS, B. J. \& HEMMELGARN, B. R. 2015. Comorbidity as a driver of adverse outcomes in people with chronic kidney disease. Kidney International, 88, 859-866.

TONETTI, M. S., D'AIUTO, F., NIBALI, L., DONALD, A., STORRY, C., PARKAR, M., SUVAN, J., HINGORANI, A. D., VALLANCE, P. \& DEANFIELD, J. 2007. Treatment of periodontitis and endothelial function. New England Journal of Medicine, 356, 911-920.

TRIVEDI, M., PASARI, A., CHOWDHURY, A., KURIEN, A. \& PANDEY, R. 2017. The epidemiology, clinical features, and outcome of infection-related glomerulonephritis from East India: A single center experience. Indian journal of nephrology, 27, 307.

USHER, A. K. H. \& STOCKLEY, R. A. 2013. The link between chronic periodontitis and COPD: a common role for the neutrophil? BMC Medicine, 11, 241.

VAN DYKE, T. E. \& DAVE, S. 2005. Risk Factors for Periodontitis. Journal of the International Academy of Periodontology, 7, 3-7.

VANHOLDER, R., DE SMET, R., GLORIEUX, G., ARGILES, A., BAURMEISTER, U., BRUNET, P., CLARK, W., COHEN, G., DE DEYN, P. P., DEPPISCH, R., DESCAMPSLATSCHA, B., HENLE, T., JORRES, A., LEMKE, H. D., MASSY, Z. A., PASSLICKDEETJEN, J., RODRIGUEZ, M., STEGMAYR, B., STENVINKEL, P., TETTA, C., WANNER, C. \& ZIDEK, W. 2003. Review on uremic toxins: classification, concentration, and interindividual variability. Kidney Int, 63, 1934-43. 
VAZIRI, N. D., PAHL, M. V., CRUM, A. \& NORRIS, K. 2012. Effect of uremia on structure and function of immune system. J Ren Nutr, 22, 149-56.

VIELKIND, P., JENTSCH, H., ESCHRICH, K., RODLOFF, A. C. \& STINGU, C.-S. 2015. Prevalence of Actinomyces spp. in patients with chronic periodontitis. International Journal of Medical Microbiology, 305, 682-688.

VILA, T., RIZK, A. M., SULTAN, A. S. \& JABRA-RIZK, M. A. 2019. The power of saliva: Antimicrobial and beyond. PLoS pathogens, 15.

VOSTI, K. L., JOHNSON, R. H. \& DILLON, M. F. 1971. Further characterization of purified fractions of M protein from a strain of group A, type 12 Streptococcus. J. Immunol. Res., 107, 104-114.

WADE, W. G. 2013. The oral microbiome in health and disease. Pharmacol. Res., 69, 137-43.

WAHID, A., CHAUDHRY, S., EHSAN, A., BUTT, S. \& ALI KHAN, A. 2013. Bidirectional Relationship between Chronic Kidney Disease \& Periodontal Disease. Pak J Med Sci, 29, 211-215.

WHITMORE, S. E. \& LAMONT, R. J. 2011. The pathogenic persona of community associated oral streptococci. Molecular microbiology, 81, 305-314.

WINNING, L., PATTERSON, C. C., CULLEN, K. M., STEVENSON, K. A., LUNDY, F. T., KEE, F. \& LINDEN, G. J. 2015. The association between subgingival periodontal pathogens and systemic inflammation. J Clin Periodontol, 42, 799-806.

YAMANAKA, T., FURUKAWA, T., MATSUMOTO-MASHIMO, C., YAMANE, K., SUGIMORI, C., NAMBU, T., MORI, N., NISHIKAWA, H., WALKER, C. B., LEUNG, K. P. \& FUKUSHIMA, H. 2009. Gene expression profile and pathogenicity of biofilm-forming Prevotella intermedia strain 17. BMC Microbiol, 9, 11.

YOSHIZAWA, N., OSHIMA, S., TAKEUCHI, A., KONDO, S., ODA, T., SHIMIZU, J., NISHIYAMA, J., ISHIDA, A., NAKABAYASHI, I. \& TAZAWA, K. 1997. Experimental acute glomerulonephritis induced in the rabbit with a specific streptococcal antigen. Clinical \& Experimental Immunology, 107, 61-67.

ZABRISKIE, J. B., LEWSHENIA, R., MÖLLER, G., WEHLE, B. \& FALK, R. E. 1970.

Lymphocytic responses to streptococcal antigens in glomerulonephritic patients. Science, 168, 1105-1108.

ZHANG, J., JIANG, H., SUN, M. \& CHEN, J. 2017. Association between periodontal disease and mortality in people with CKD: a meta-analysis of cohort studies. BMC Nephrology, 18, 269.

ZHAO, D., KHAWAJA, A. T., JIN, L., LI, K. Y., TONETTI, M. \& PELEKOS, G. 2018. The directional and non-directional associations of periodontitis with chronic kidney disease: A systematic review and meta-analysis of observational studies. J Periodontal Res, 53, 682-704.

ZIJNGE, V., VAN LEEUWEN, M. B. M., DEGENER, J. E., ABBAS, F., THURNHEER, T., GMÜR, R. \& M. HARMSEN, H. J. 2010. Oral Biofilm Architecture on Natural Teeth. PLOS ONE, 5, e9321.

ZOELLNER, H., CHAPPLE, C. C. \& HUNTER, N. 2002. Microvasculature in gingivitis and chronic periodontitis: disruption of vascular networks with protracted inflammation. Microscopy research and technique, 56, 15-31. 